\title{
The use of network analysis in the process of delimitation as exemplified by the administrative division of Poland
}

\author{
Marta Borowska-Stefańska*, Szymon Wiśniewski \\ University of Łódź \\ Institute of the Built Environment and Spatial Policy \\ 90-142 Łódź, Kopcińskiego Street 31, Poland \\ e-mails: borosia@op.pl, szymon.wisniewski@geo.uni.lodz.pl \\ * Corresponding author: Marta Borowska-Stefańska
}

Received: 23 July / Accepted: 24 August 2017

\begin{abstract}
The cognitive aim of this study is to point to the optimum number of local government units and the optimum boundaries of spatial units in Poland with the assumption of minimizing the cumulated theoretical travel time to all settlement units in the country. The methodological aim, in turn, is to present the use of the ArcGIS location-allocation tool for the purposes of delimitation processes as exemplified by administrative boundaries in Poland. The rationale for the implementation of this study is that number and the boundaries of units of all levels of Poland's current territorial division are far from optimum in the light of minimization of accumulated theoretical travel time to all settlement units in the country. It may be concluded that it would be justifiable to increase the number of voivodships from the current number of 16 to 18. Besides it would be necessary to introduce modifications in relation to units with regional functions. In contrast, the number of districts and communes should be reduced. A continuation of this research may go in the direction of including analysis of public transport network in the research, creating in this way a multimodal set of network data. This would illustrate, apart from the potential itself resulting from the infrastructure, also the actually existing connections.
\end{abstract}

Keywords: spatial accessibility, administrative division, network analysis, GIS, Poland.

\section{Introduction}

Colossal changes with regard to public administration management were introduced in many European countries between 1970 and 2000. The main reforms concerned changes in relations between the central, regional and local levels of administration in the design of public policies and in the evaluation of administrative outcomes and outputs. The reforms in question were also implemented in the countries of Central 
and Eastern Europe, including Poland (Nikos, 2000; Ongaro, 2009). The literature which refers to these issues contains attempts to answer questions on the nature of this phenomenon, its range, reasons for it as well as possible consequences of changes (Aucoin, 1990; Barzelay, 2001; Dunleavy and Hood, 1994; Ferlie et al., 1996, 2005; Hood, 1991 and 1995; Kettl, 2000; Lynn, 1996; Ongaro, 2009; Peters and Olsen, 1996; Pollitt, 1993; Pollitt and Bouckaert, 2004 The shape of national political systems was affected in Poland by its EU membership (as in other countries which joined the EU), (Kelley, 2004a; 2004b; 2006; Vachudova, 2005; Schimmelfennig, 2003; Jacoby, 2004).

Poland is one of those countries which fairly frequently introduced changes to their administrative structure in the 20th century. Reconstruction of territorial divisions in the previous century affected all tiers of the structure. The number and shape of voivodships underwent numerous changes (1938-1939, 1945-1946, 1950, 1956-1957, 1975, 1999, they were also replaced by districts in the years 1954-1972). Changes to the country's administrative division tended to be rather controversial and gave rise to numerous proposals of alterations (Sokołowski, 2014). The latest reform conducted in 1999 also failed to rise to the expectations (Zaborowski, 2016a).

As a result of its implementation, now there are 16 voivodships in Poland (two of them, the Kujawsko-Pomorskie and Lubuskie voivodship, have two capitals each - separately the seat of the Governor and the Provincial Assembly, the remaining voivodships have one capital each) which correspond to the EU NUTS 2 level (Bronisz et al., 2008).

Most objections concern districts and in the first place it is worth stressing their weak competences resulting from insufficient number and range of financed public functions. In second place are mentioned voivodships, which in some cases are too large areas and, so, fail to provide good accessibility to their capitals, or they are too small to be able to maintain public services at a high level, which concerns the Lubuskie voivodship and the Opolskie voivodship. As research shows in the light of the gravity analysis, both the number and boundaries of present voivodships are far from optimum. As opposed to the current number of voivodships, which is 16, it seems more justifiable to have a division of the country into 14 or 18-20 units of this type. Communes alone are by far least criticized, which surely results from their long tradition. In the case of the lowest tier of Poland's administrative division, border disputes are merely local in character (Śleszyński, 2015). Moreover, it is common knowledge that the country's development is of polarization character and tends to be evaluated in a negative way. Social and economic polarization results from adoption of territorial division into units which are too large and strengthening of several selected settlement units. Not only do the capitals of regions concentrate the most important functions (especially those of metropolitan character and higher level) but they also are efficient at "draining" centres which are positioned lower in the administrative and settlement hierarchy of this type of activity.

So far transport accessibility has not been defined in one universal and prevailing manner and it is highly likely that such a definition will not be elaborated in the 
future. P. Gould (1969) points out that accessibility is one of those commonly used terms that everyone uses yet nobody can define or measure it once and for all. One of the definitions most frequently quoted in the literature of the subject is that proposed by W.G. Hansen (1959), according to which accessibility is described as the potential opportunities for interaction. In turn, S.L. Handy and D.A. Niemeier (1997) stress that interactions should be understood in a broad sense both economic and social. F.R. Bruinsma and P. Rietveld (1998) point at yet another possible definition of accessibility, namely "the ease of spatial interactions" or more precisely as: "attractiveness of a node in a network taking into account the mass of other nodes and the costs to reach those nodes via the network". D.R. Ingram (1971) points to a similar definition in the light of which accessibility is understood as points to a similar definition, in the light of which accessibility is an inherent characteristic of place operationalized in terms of overcoming some form of friction, e.g. in the form of physical or temporal distance. Irrespective of the definition adopted, most authors point to the existence of certain components, segments or elements which are indispensable for appropriate understanding of the problem and which comprise the integral ingredients of transport accessibility (Dalvi and Martin, 1976).

The final vital reason why it is worth discussing the justifiability, number and geographical range of different level territorial units refers to the expected changes in the distribution of the population connected with depopulation of large parts of the country. In the future a major qualitative change will consist in depopulation of not only peripheral rural regions but also almost all town categories. A decrease in the number of the population combined with deteriorating age structure will erode the economic foundations of cities and regions. As a result, the budget income of different tier units will shrink, which, in turn, will lead to their inability to maintain services on the same level. Costs of these will rise due to the bigger share of people at retirement age who require increased care. On all levels of local administration it may be necessary to reduce the number of units performing certain administrative functions (e.g. district ones) and to increase the area (e.g. the number of communes comprising the given higher-tier unit). This may, in turn, lead to a drop in the effectiveness of different systems and need for more efficient spatial development (e.g. in relation to the network of schools, roads, etc.). Analyses on the assessment of functioning of local government units are conducted on the government level. Regrettably, the discussion is currently mostly aimed at self-sufficiency of communes whereas there is a deficiency of more advanced studies on similar issues in relation to higher tiers of local governments concerning not only their income but also, for instance, growing social and economic polarization (Śleszyński, 2015).

Research into the network of main settlement units is carried out in literature mainly from two perspectives: that of potential resulting from the size and location as well as from the viewpoint of the factual functional hierarchy. Unfortunately, the territorial division of Poland into 16 voivodships, including 18 voivodship cities, which was introduced in 1999, fails to correspond to any concept proposed by the 
scientific circles or factual significance of cities as management centres or units which perform central functions. This is why is seems justifiable to discuss this issue again (Zaborowski, 2014).

The cognitive aim of this study is, therefore, to point to the optimum number of local government units in Poland with the assumption of minimizing the cumulated theoretical travel time to all settlement units in the country.

The methodological aim, in turn, is to present the use of the ArcGIS locationallocation tool for the purposes of delimitation processes as exemplified by administrative boundaries in Poland.

\section{Data used and methods applied}

Considerations concerning physical distances were ignored at the stage of analyses of accessibility in car transport due to their increasingly marginal importance in choices of travellers since in practice it is not uncommon that extending the route proves cost-effective as it enables achieving a higher speed and performing carrier tasks in a shorter time. This situation illustrates the phenomenon of substitution, or replacing the spatial distance with time distance (Gęsiarz, 1982). The study also did not take into account the economic cost of travel (such as highway tolls). Measuring travel time in individual transport is a rather complicated task as this parametre is determined by many factors, such as weather conditions, unpredicted road occurrences (e.g. accidents) or individual features of drivers, and moreover it varies in its daily, weekly and yearly distribution. Considerations related to the influence of these factors on vehicle traffic are devoted numerous road traffic engineering studies (for example: Gaca et al., 2011 or Agarwal et al., 2013).

The variant of research into travel time presented in this article assumes only one determinant conditioning the speed of vehicles: restrictions resulting from Traffic Law Act. In this way net travel times were determined not taking into consideration either breaks resulting from conditions on the road or breaks allowing the driver to rest or tank. It was assumed that vehicles move at the maximum permissible speed on routes which allow the shortest possible travel time. Consequently, journeys on tolled fragments of motorways were also taken into consideration. While determining accessibility, every time the shortest route was sought in the temporal sense, which did not always overlap with the shortest route in accordance with the real physical distance.

Transport accessibility may be researched in a number of ways. Some authors name as many as over a dozen of them (Bruinsma and Rietveld, 1998). In most works devoted to this problem, however, there is certain consensus concerning the existence of a few fundamental methods (Baradaran and Ramjerdi, 2001; Geurs and van Wee, 2004; Geurs and Ritsema van Eck, 2001; Spiekermann and Neubauer, 2002). It is worth pointing out, for instance, infrastructure-based accessibility, distancebased accessibility, cumulative accessibility, potential accessibility, or person-based 
accessibility (Rosik, 2012). It should be emphasized here that accessibility studies require taking into account three main points - start and end points, means of transport and forms of space resistance.

This research uses two from the above approaches. The author introduced analysis based on measurements of distance where distance is understood as physical distance (Euclidean), real physical distance (e.g. road distance), temporal (time of travel/carriage) or economic (cost of travel/carriage) between the source of journey and its destination or a set of destinations as well as cumulative accessibility. The cumulative method allows you to determine the level of accessibility by presenting the cumulative number of arbitrary objects (depending on the assumptions of the analysis) within the range of the assumed cost (expressed in time, distance or money) of the trip from the starting point of the survey (Wiśniewski, 2017). Isochronic accessibility is a presentation method for the cumulative approach. In areas limited by individual isolines, such as the population or elements of spatial development, are counted.

Overall, while measuring accessibility by means of isochrones it is necessary to assume certain maximum time and cost (travel budget). Subsequently, the number of destinations accessible in the time given or with the adopted cost is calculated (Spiekermann and Neubauer, 2002). Other examples of research into daily accessibility: Törnquist (1970), Schürmann et al. (1997), Spiekermann and Wegener (1996), Vickerman et al. (1999), O'Sullivan et al. (2000), Gutiérrez (2001), Martin et al. (2004), Du and Mulley (2006), Preston and Raje (2007), Biosca et al. (2013), Ford et al. (2015), Śleszyński (2017).

The collected source materials and methodological assumptions entailed the following research proceedings. The first step consisted in constructing a transport network on the basis of which travel times were subsequently calculated. At this stage every segment of the network was ascribed the maximum allowed speed of travelling on it. This, in turn, allowed to estimate the travel time of the segment, and finally calculate the quickest route between the adopted points in accordance with the Dijkstra's algorithm. Subsequently, all analyzed elements of the country's land development were charted on the transport network. Settlement units were ascribed their central points so that they can be later calculated with the cumulative method. The subsequent stage of the research was to delineate routes between starting points and destinations selected for the analysis.

In order to accomplish the adopted research assumptions the author used tools for network analysis available in ArcMap. To achieve this it was necessary to use data from the OpenStreetMap database. These are free data available for the whole world (Haklay and Weber, 2008; Cichociński, 2012; Nowak Da Costa, 2016).

This tool allows to choose the smallest possible number of locations (facilities) from the 52,704 settlement units (points of demand) introduced to the analysis so that each of them has a connection with one selected location, minimizing at the same time the total cost of travel from the time perspective. The research was conducted for six variants of maximum travel time from 
30 to 180 minutes in 30-minute intervals. In Network Analyst tools it is possible to specify the number of regional centers (regions). It is also possible to determine the value of transport costs (time, distance, money) over which the program will no longer seek transport links between the regional center and other settlement units.

Time scopes were adopted, taking into account numerous research devoted to delineating areas of influence of local authorities centres (e.g. BalaguerColl et al., 2007; Friend and Jessop, 2013; Roberts et al., 2016) depending on their level whose results appeared in scientific publications or technical reports whose aim is, for instance, to delineate metropolitan areas or functional urban areas.

\section{Results}

In the first stage of the analysis the author adopted the assumption of optimum distribution of 16 voivodship centres in Poland with the simultaneous minimization of theoretical travel time to all settlement units in Poland. It was established that the present boundaries of voivodships are not quite delineated in the best possible way, they do not ensure good accessibility to their capitals. It was concluded that the division of Poland into voivodships which was in force between 1945 and 1946 was markedly the best (it ensured better accessibility to voivodship capitals) in particular with reference to the boundaries of the former Poznańskie voivodship or the Wrocławskie voivodship. Bearing in mind the minimization of theoretical travel time, the smallest corrections of boundaries of the present voivodships refer to the Podkarpackie voivodship, whereby its capital should be situated at a distance of about 40-50 km (in a straight line) south west of Rzeszów (the present capital of the voivodship), i.e. in the neighbourhood of Krosno. It also seems necessary to slightly alter the boundaries of the KujawskoPomorskie voivodship with its capital in Bydgoszcz. The biggest changes would concern the following voivodships of Mazowieckie, Wielkopolskie, Podlaskie and Lubelskie (Figure 1).

The aim adopted in the subsequent stage of the analysis consists in optimum distribution of centres with the assumption of maximum 30-minute theoretical travel time to all settlement units in Poland. In this case Poland should have 1,094 local government centres (Figure 2; Table 1). Currently there are 2,479 communes, 380 districts and 16 voivodships in Poland. Hence the results of the research do not coincide with any present tier of local administration in Poland, and these analyses may point to a necessity to reduce the number of communes. 


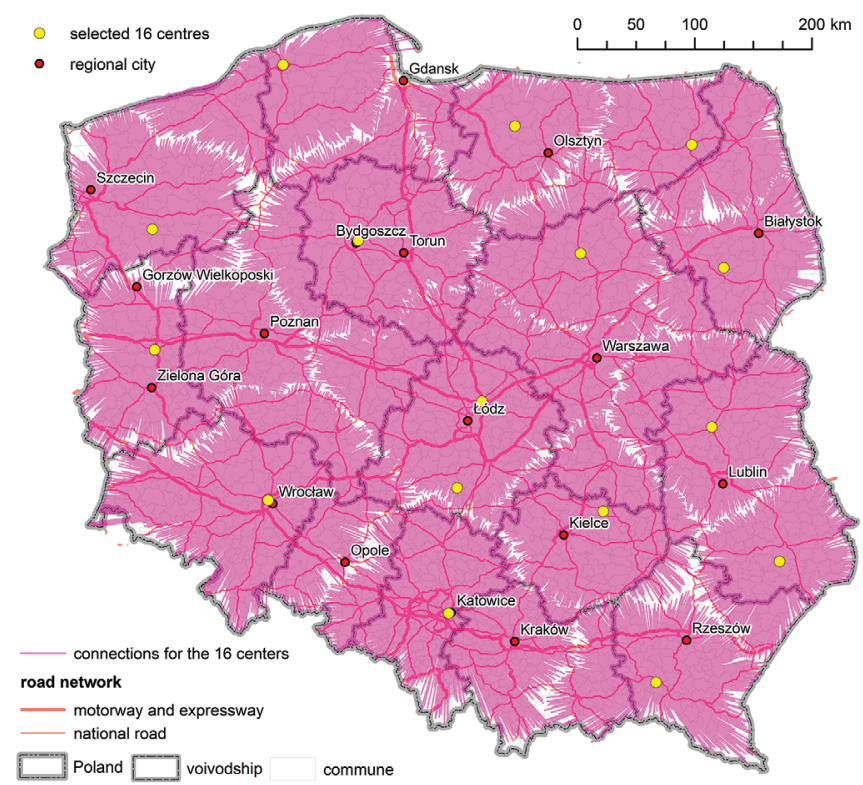

Fig. 1. Optimum distribution of 16 centres with the assumption of minimizing theoretical travel time to all settlement units in Poland

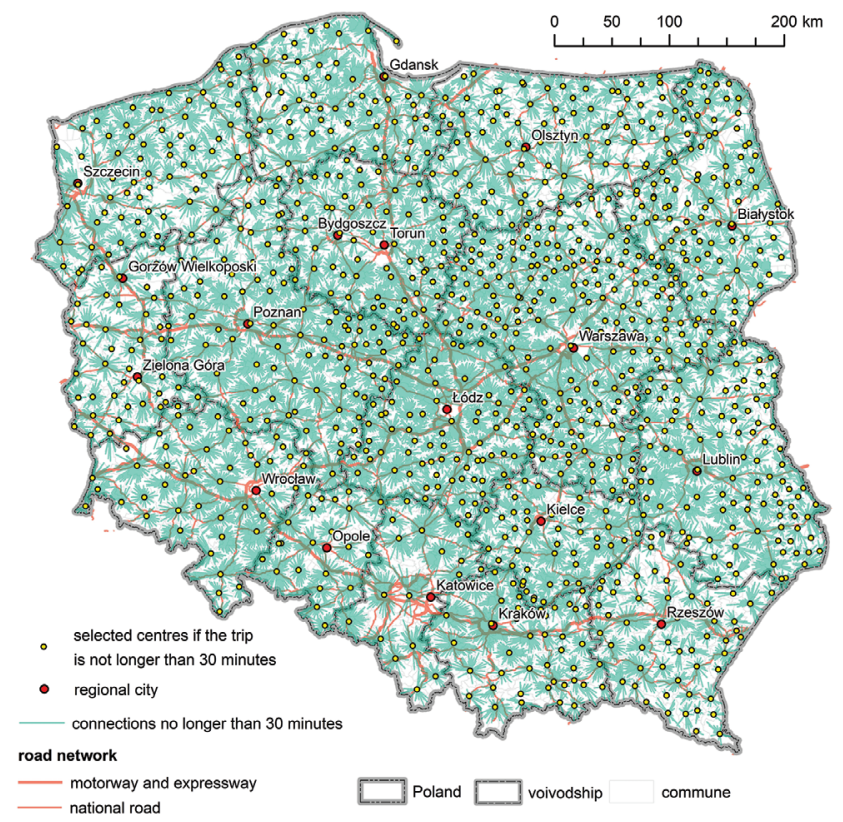

Fig. 2. Optimum distribution of regional centres with the assumption of maximum 30-minute theoretical travel time to all settlement units in Poland 
Then the minimum travel time to all settlement units in Poland was extended to 60 minutes, as a result of which it was concluded that the minimum number of local government centres on the area in question should be 151 (Figure 3; Table 1). This value, however, is too small in relation to the existing number of districts and too big if these centres were to perform functions of regional or countrywide character (Werwicki, 1973).

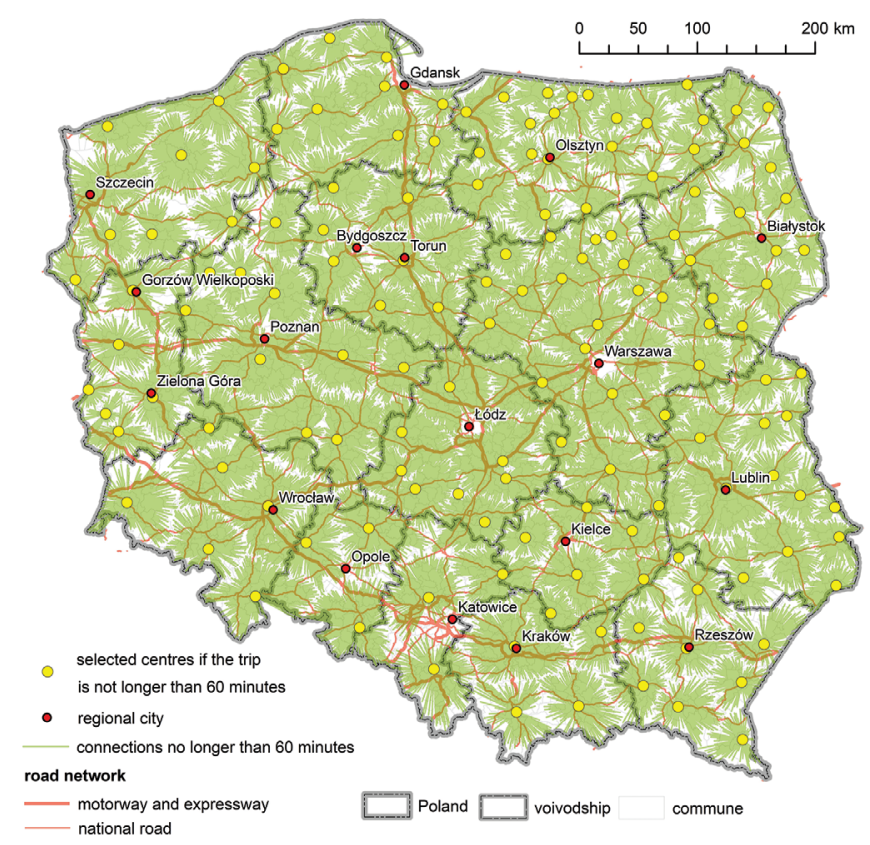

Fig. 3. Optimum distribution of regional centres with the assumption of maximum 60-minute theoretical travel time to all settlement units in Poland

In turn, if the minimum travel time to all settlement units in Poland is extended to 90 minutes, the number of local government centres drops to 40 (Figure 4; Table 1). This value is close to the administrative reform in force between 1975 and 1998, when there were 49 voivodships in Poland and voivodship cities had, in some cases, less than 50 thousand inhabitants. 


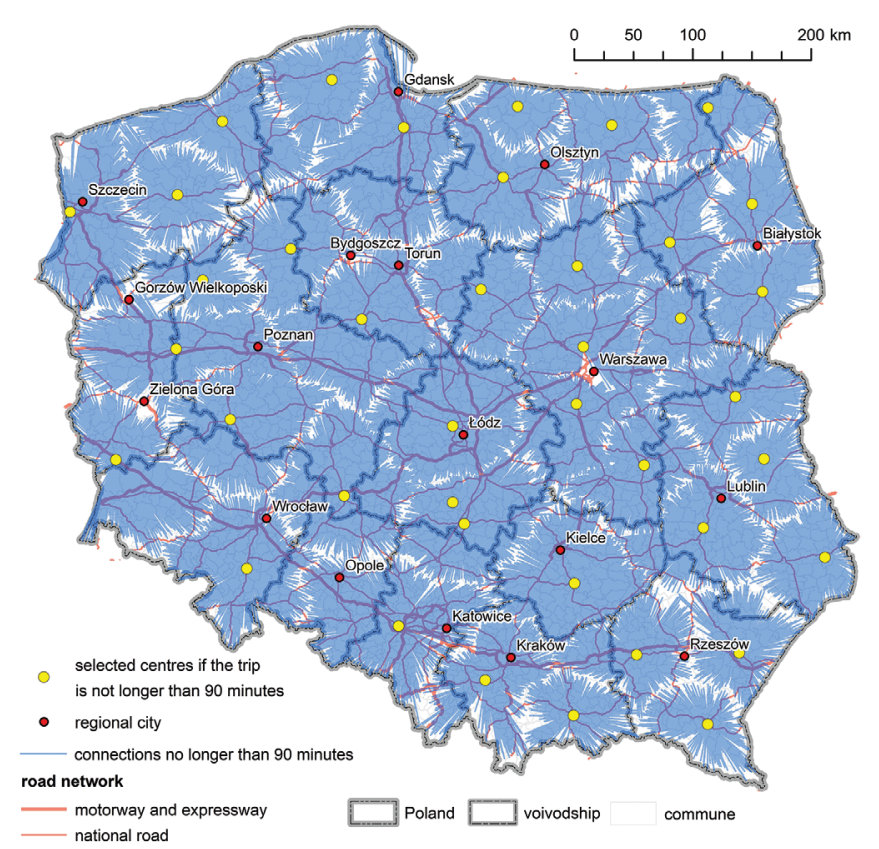

Fig. 4. Optimum distribution of regional centres with the assumption of maximum 90-minute theoretical travel time to all settlement units in Poland

In the subsequent stage of the analysis the author adopted the optimum distribution of centres, with the assumption of maximum 120-minute theoretical travel time to all settlement units in Poland. In this case the minimum number of voivodship centres is 18 and it is the closest to the present administrative division of Poland introduced in 1999 (nowadays there are 16 voivodships and and 18 capitals). Yet if this division is adopted, the Łódzkie voivodship should have two voivodship centres. An additional centre should be carved in the north-eastern Poland from Podlaskie voivodship and the WarmińskoMazurskie voivodship and its capital should be located near Olecko. The Małopolskie voivodship and the Śląskie voivodship should be joined with the capital in Kraków. Due to the adopted travel time nowadays it is voivodship towns that have the most advantageous location, such as Kraków, Łódź, Wrocław or Olsztyn (Figure 5; Table 1).

In the last stage of analysis the aim was to achieve the optimum distribution of centres with the assumption of maximum 150-minute, and then 180-minute, theoretical travel time to all settlement units in Poland. In the first case Poland should have 10 voivodship centres whereas in the latter -7 voivodship centres, which, in turn, insufficient (Figure 6; Figure 7; Table 1). 


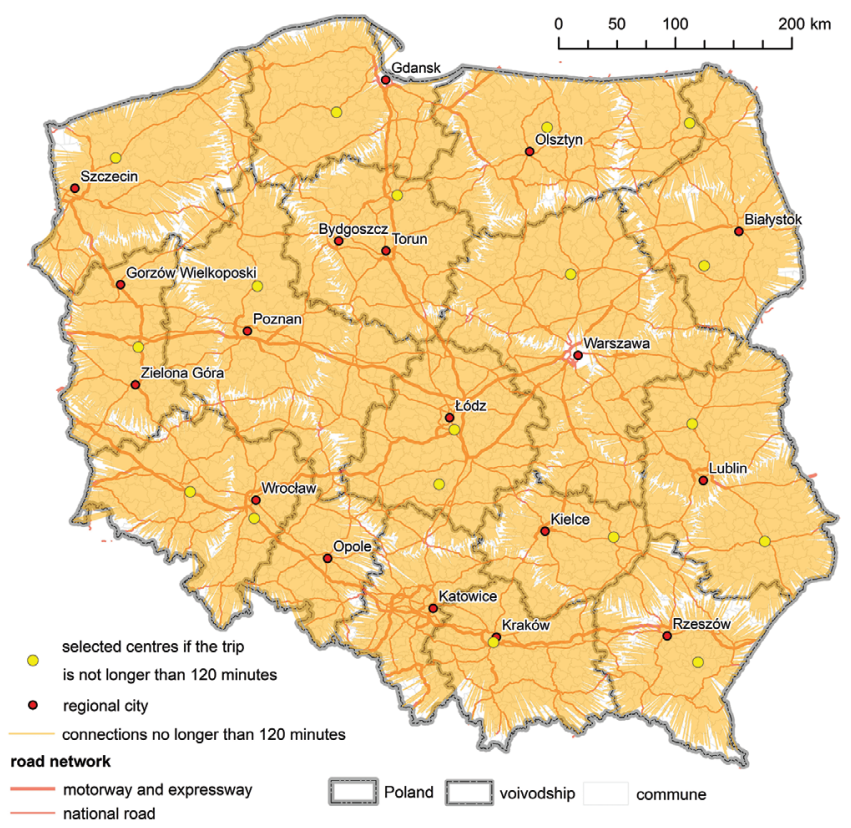

Fig. 5. Optimum distribution of regional centres with the assumption of maximum 120-minute theoretical travel time to all settlement units in Poland

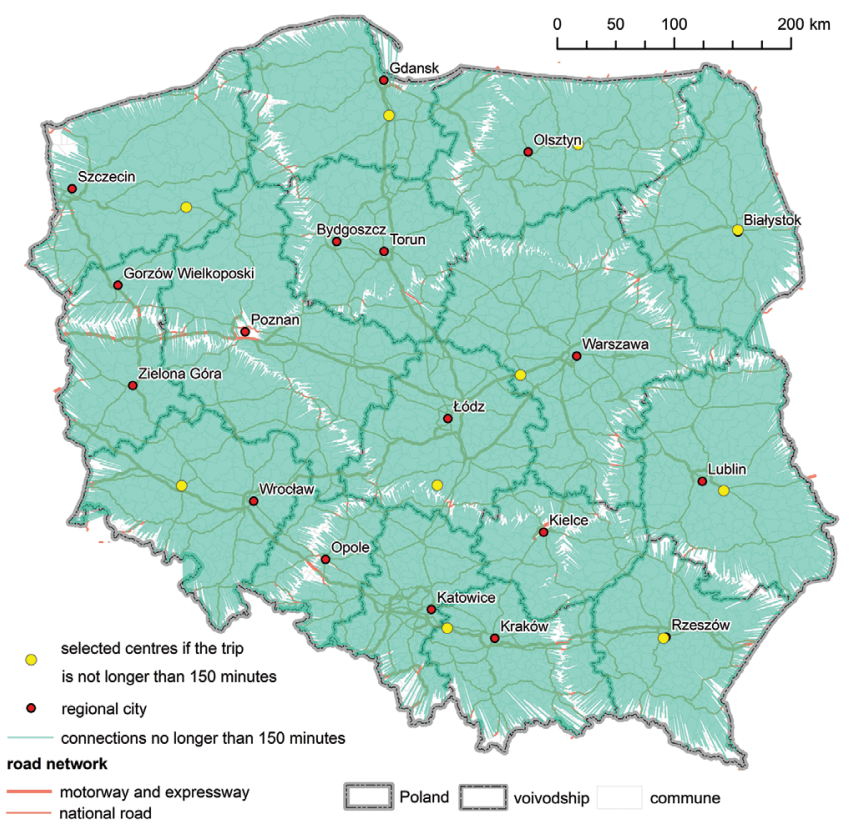

Fig. 6. Optimum distribution of regional centres with the assumption of maximum 150-minute theoretical travel time to all settlement units in Poland 


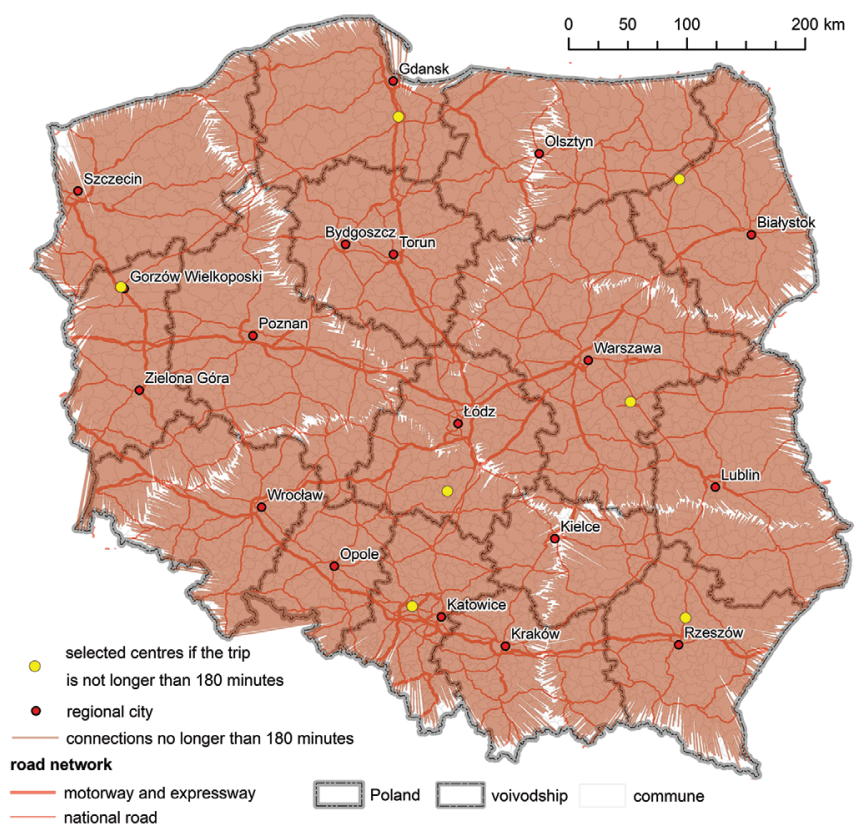

Fig. 7. Optimum distribution of regional centres with the assumption of maximum 180-minute theoretical travel time to all settlement units in Poland

Table 1. The minimum number of centres with the assumed maximum travel time

\begin{tabular}{|c|c|}
\hline Maximum travel time $[\mathrm{min}]$ & Minimum number of centres \\
\hline 30 & 1094 \\
\hline 60 & 151 \\
\hline 90 & 40 \\
\hline 120 & 18 \\
\hline 150 & 10 \\
\hline 180 & 7 \\
\hline
\end{tabular}

Voivodships would have huge surfaces and travel time from other centres to them would pose a hindrance to a considerable number of the population. 


\section{Discussion}

Both the number and the boundaries of units of all levels of Poland's current territorial division are far from optimum in the light of minimization of accumulated theoretical travel time to all settlement units in the country. It would be justifiable to increase the number of voivodships from the current number of 16 to 18 . Selection of voivodship centers was made not on the basis of objective evidence, but on a discretionary basis, by way of political bargaining. This is a problem indelible except through rational correction system. The principle here must be equal treatment of similar centers and regions (Zaborowski, 2016a). Another reason to change the current allocation would be excessive concentration of development potential in Warsaw, which adversely affects the development of other urban centers in Poland (Zaborowski, 2016b). Sustainable development of the country requires constant opposition to excessive centralization and support polycentric system of urban centers. With the equally important is the development of big cities and provincial, as well as - in large voivodships - subregional centers. Besides it would be necessary to introduce modifications in relation to units with regional functions. In contrast, the number of districts and municipalities should be reduced. Due to the introduction of modifications to the administrative boundaries with the use of the proposed method it would be possible to avoid excessive disproportions which are the main cause of the country's social and economic polarization. In addition, this would lead to increased effectiveness of social and economic systems of different types, especially those of settlement and transport character. The greatest differences in the course of boundaries on the highest level of Poland's administrative division concern, in particular, the following voivodships: Lubelskie, Małopolskie, Śląskie and Mazowieckie.

Determining boundaries of local authorities with the minimization of accumulated theoretical travel time to all settlement units in the country is naturally not the only method which points to spatial incoherence of the current territorial division. Similar conclusions were also presented by Śleszyński (2015) who, nevertheless, used the gravity method in his research. On the basis of the conducted research he arrived at a conclusion that it would be justifiable in relation to the existing 16 voivodships either to reduce the number of units to 14 or increase it to $18-20$. In this way it would be possible to avoid excessive disproportions which are one of the reasons for the country's social and economic polarization. Likewise, this is also one of the causes of lower than achievable effectiveness of performance of different kinds of social and economic systems, especially settlement and transport ones.

Moreover, research into journeys to work has indicated that there are about 150 natural regions of gravity of this type in the whole country (Gruchociak, 2012; Śleszyński, 2014). Similar correlations have been defined for regions on the basis of migration matrix (Śleszyński, 2011). Also analysis into time and transport accessibility point to clear peripheral areas from which travel time by car to regional capitals exceeds, in some cases, up to 3 hours (Komornicki et al., 2009). On the other hand, there are many arguments concerning hypertrophy and Warsaw, consisting in strong hypertrophy 
of high-specialized services, especially economic control functions (Lijewski, 2003; Śleszyński, 2007), which adversely affects also the model of functional connections dominated by the capital in the context of regional development and territorial cohesion (Śleszyński, 2008), manifesting itself especially in polarization on the job market and forcing employees to commute long distances (Śleszyński, 2013).

The results of this research represent merely some simplified analyses in reference to the administrative division of Poland. It is worth stressing, however, that they do not account for many other important factors connected with delimitation of regions for practical purposes such as their territorial management. This concerns, above all, environmental and historical determinants as well as functional connections which are being shaped nowadays. Such attempts, however, should be made as changes to the present administrative division of Poland seem to be more and more needed.

\section{Conclusion}

Due to the applied method consisting in minimizing the cumulated theoretical travel time to all settlement units it is possible to implement a more effective administrative division on the local, regional and national level not only in Poland but also in other countries. The example of Poland shows that although changes introduced in the late 20th century in relation to the administrative structure were necessary, they failed to rise up to expectations. The currently existing administrative division has led to very large disproportions in the country's social and economic development which could be minimized though increasing the number of voivodships and delineating their new boundaries.

The obtained results may naturally represent only one among many voices in the discussion accompanying delineation of all kinds of boundaries. The indicated approach brings "hard" arguments expressed in units of time or distance, and it is apparent that boundaries (particularly on the regional level) are more than just a result of some calculations. However, the implementation of the presented method to the process of delimitation seems justified due to the high speed of the analysis (allowing to account for many research variants) on large data sets and the ease of interpretation of the results.

The presented analysis does not differentiate settlement units at all, only their location in the country's transport network is taken into account. This simplification may naturally be perceived as too far-reaching but, on the other hand, the obtained results tend to be totally objective, free from any "distortions" which accompany more advanced methods whose results are dependent, to a variable extent, on the researcher, e.g. through introduction of different types of coefficients.

A continuation of this research may go in the direction of including analysis of public transport network in the research, creating in this way a multimodal set of network data. This would illustrate, apart from the potential itself resulting from the infrastructure, also the actually existing connections. 


\section{Acknowledgment}

We give here our thanks to "blind" Reviewer for his substantive help and tips for this article.

\section{References}

Agarwal, S., Kodialam, M. and Lakshman, T. V. (2013). Traffic engineering in software defined networks. In INFOCOM, 2013 Proceedings IEEE, pp. 2211-2219, IEEE. DOI 10.1109/INFCOM.2013.6567024

Aucoin, P. (1990). Administrative Reform in Public Management: Paradigms, Principles, Paradoxes and Pendulums, Governance, 3 (2), pp. 115-137. DOI 10.1111/j.1468-0491.1990.tb00111.x

Balaguer-Coll, M. T., Prior, D. and Tortosa-Ausina, E. (2007). On the determinants of local government performance: A two-stage nonparametric approach. European Economic Review, 51(2), 425-451. DOI 10.1016/j.euroecorev.2006.01.007

Baradaran, S. and Ramjerdi, F. (2001). Performance of Accessibility Measures in Europe, Journal of Transportation and Statistics, 4 (2/3), 31-48.

Barzelay, M. (2001). The New Public Management: Improving Research and Policy Dialogue. Berkeley California \& New York: University of California Press \& Russell Sage Foundation.

Biosca, O., Spiekermann, K. and Stępniak, M. (2013). Transport accessibility at regional scale. Europa XXI, 24, 5-17. DOI /10.7163/Eu21.2013.24.1

Bronisz, U., Heijman, W. and Miszczuk, A. (2008). Regional competitiveness in Poland: Creating an index. Jahrbuch für Regionalwissenschaft, 28 (2), 133-143. DOI 10.1007/s10037-008-0026-y

Bruinsma, F.R. and Rietveld P. (1998). The Accessibility of European Cities: Theoretical Framework and Comparison of Approaches. Environment and Planning, 30 (3), pp. 499-521. DOI 10.1068/a300499

Cichociński, P. (2012). Ocena przydatności OPENSTREETMAP jako źródła danych dla analiz sieciowych. Roczniki Geomatyki, 10.7 (57), 15-24.

Dalvi, M.Q. and Martin, K.M. (1976). The measurement of accessibility: some preliminary results. Transportation, 5 (1), 17-42.

Du, H. and Mulley, C. (2006). Relationship between transport accessibility and land value: Local model approach with geographically weighted regression. Transportation Research Record: Journal of the Transportation Research Board, (1977), 197-205. DOI 10.3141/1977-25

Dunleavy, P.J. and Hood, C. (1994). From Old Public Administration to New Public Management'. Public Money and Management, 14 (3), pp. 9-16. DOI 10.1080/09540969409387823

Ferlie, E., Pettigrew, A., Ashburner, L. and Fitzgerald, L. (1996). The New Public Management in Action, Oxford, Oxford University Press.

Ferlie, E., Lynn, L. E. and Politt, Ch., (2005) (ed.). The Oxford Handbook of Public Management, Oxford University Press.

Ford, A. C., Barr, S. L., Dawson, R. J. and James, P. (2015). Transport accessibility analysis using GIS: Assessing sustainable transport in London. ISPRS International Journal of Geo-Information, 4(1), 124-149. DOI 10.3390/ijgi4010124

Friend, J. and Jessop, N. (2013). Local Government and Strategic Choice (Routledge Revivals): An Operational Research Approach to the Processes of Public Planning. Routledge.

Gaca, S., Suchorzewski, W. and Tracz, M. (2011). Inżynieria ruchu drogowego: teoria i praktyka. Wydawnictwa Komunikacji i Łączności.

Geurs, K.T. and van Wee, B. (2004). Accessibility Evaluation of Land-use and Transport Strategies: Review and Research Directions. Journal of Transport Geography, 12 (2), 127-140. DOI 10.1016/j. jtrangeo.2003.10.005

Geurs, K.T. and Ritsema van Eck (2001). Accessibility Measures: Review and Applications. RIVM report 408505 006, National Institute of Public Health and the Environment, Bilthoven.

Gęsiarz, Z. (1982). Zarys geografii transportu. WSiP, Warsaw. 
Gould, P. (1969). Spatial Diffusion. Resource Paper No. 17, Washington, DC: Association of American Geographers.

Gruchociak, H. (2012). Odległość w wyodrębnianiu stref wpływu wielkich miast w Polsce, [in:] E. Gołata (ed.), Analiza wielowymiarowa w badaniach społeczno-ekonomicznych. Zeszyty Naukowe 227, 107-125.

Gutiérrez, J. (2001). Location, economic potential and daily accessibility: an analysis of the accessibility impact of the high-speed line Madrid-Barcelona-French border. Journal of transport geography, 9(4), 229-242. DOI 10.1016/S0966-6923(01)00017-5

Haklay, M. and Weber, P. (2008). OpenStreetMap: User-Generated Street Maps. IEEE Pervasive Computing, October-December, 7 (4), 12-18. DOI 10.1109/MPRV.2008.80

Handy, S.L. and Niemeier, D.A. (1997). Measuring Accessibility: an Exploration of Issues and Alternatives. Environment and Planning A, 29 (7), 1175-1194. DOI 10.1068/a291175

Hansen, W.G. (1959). How Accessibility Shapes Land-use. Journal of the American Institute of Planners, 25(2), 73-76.

Hood, C. (1991). A public management for all seasons?, Public Administration, 69(1), 3-19. DOI 10.1111/j.1467-9299.1991.tb00779.x

Hood, C. (1995). The 'new public management' in the 1980s: variations on a theme, Accounting. Organizations and Society, 20 (2-3), 93-109.DOI 10.1016/0361-3682(93)E0001-W

Ingram, D.R. (1971). The Concept of Accessibility: a Search for an Operational Form. Regional Studies, $5(2), 101-107$.

Jacoby, W. (2004). The Enlargement of the European Union and NATO: Ordering from the Menu in Central Europe, Cambridge: Cambridge University Press.

Kelley, J. (2004a). Ethnic Politics in Europe: The Power of Norms and Incentives, Princeton: Princeton University Press.

Kelley, J. (2004b). International Actors on the Domestic Scene: Membership Conditionality and Socialization by International Institutions. International Organization, 58 (3), 425-457. DOI $10.1017 / \mathrm{S} 0020818304583017$

Kelley, J. (2006). New wine in Old Wineskins: Promoting Political Reforms through the New European Neighbourhood Policy. JCMS, 44 (1), 29-55. DOI 10.1111/j.1468-5965.2006.00613.x

Kettl, D.F. (2000). Public administration at the millennium: the state of the field. Journal of Public Administration Research and Theory, 10 (1), 7-34. DOI 10.1093/oxfordjournals.jpart.a024267

Komornicki, T., Śleszyński, P., Rosik, P. and Pomianowski, W. (2009): Dostępność przestrzenna jako przestanka ksztaltowania polskiej polityki transportowej. Biuletyn KPZK PAN 241, Warsaw.

Lijewski, T. (2003). Koncentracja ośrodków aktywności gospodarczej w Polsce w świetle list 500 firm. Przeglad Geograficzny, 75 (3), 433-447.

Lynn, L.E. (1996). Public Management as Art, Science and Profession, Chatham House, Chatham N.J.

Martin, J. C., Gutierrez, J., and Román, C. (2004). Data envelopment analysis (DEA) index to measure the accessibility impacts of new infrastructure investments: The case of the highspeed train corridor Madrid-Barcelona-French border. Regional Studies, 38(6), 697-712. DOI $10.1080 / 003434042000240987$

Nikos, M. (2000). Trends of Administrative Reform in Europe: towards administrative convergence? Paper presented at the First Regional Interactional Conference of the International Institute of Administrative Sciences, University of Bologna, 19-22 June.

Nowak Da Costa, J. (2016). Towards building data semantic similarity analysis: OpenStreetMap and the Polish Database of Topographic Objects. Geodetic Congress (Geomatics), Baltic, 2-4 June 2016, Gdansk, Poland. DOI: 10.1109/BGC.Geomatics.2016.55

Ongaro, E. (2009). Public Management Reform and Modernization. Trajectories of Administrative Change in Italy, France, Greece, Portugal and Spain, Cheltenham and Northampton, Mass., Edward Elgar.

O'Sullivan, D., Morrison, A., and Shearer, J. (2000). Using desktop GIS for the investigation of accessibility by public transport: an isochrone approach. International Journal of Geographical Information Science, 14(1), 85-104. DOI 10.1080/136588100240976

Peters, G. and Olsen, J. (1996). Lessons From Experience: Experiential Learning in Administrative Reforms in Eight Democracies, Oslo: Scandinavian University Press. 
Pollitt, C. (1993). Managerialism and the Publk Services The Anglo-American Ekperhce, 2nd Edn, Oxford: Blackwell.

Pollitt, C. and Bouckaert, G. (2004). Public Management Reform. A Comparative Analysis, Oxford University Press, Oxford ( $2^{\text {nd }}$ edition).

Preston, J. and Rajé, F. (2007). Accessibility, mobility and transport-related social exclusion. Journal of Transport Geography, 15(3), 151-160. DOI 10.1016/j.jtrangeo.2006.05.002

Roberts, P., Sykes, H. and Granger, R. (Eds.). (2016). Urban regeneration. Sage.

Rosik, P. (2012). Dostęnność lądowa przestrzeni Polski w wymiarze europejskim, Prace Geograficzne, IGiPZ PAN, Warsaw.

Schimmelfennig, F. (2003). The EU, NATO and the Integration of Europe Cambridge: Cambridge University Press.

Schürmann, C., Spiekermann, K. and Wegener, M. (1997). Accessibility Indicators: Model and Report, SASI Deliverable D5. Institute of Spatial Planning, Dortmund.

Sokołowski, D. (2014). Niektóre uwarunkowania korekty podziału Polski na województwa, Przegląd Geograficzny, 86 (4), 567-590. DOI 10.7163/PrzG.2014.4.6

Spiekermann, K. and Neubauer, J. (2002). European Accessibility and Peripherality: Concepts, Models and Indicators. Nordregio Working Paper, Stockholm.

Spiekermann, K. and Wegener, M. (1996). Trans-European Networks and Unequal Accessibility in Europe. European Journal of Regional Development, 4 (96), 35-42.

Śleszyński, P. (2007). Gospodarcze funkcje kontrolne w przestrzeni Polski, Prace Geograficzne, IGiPZ PAN, 213, Warsaw.

Śleszyński, P. (2008). Ocena powiązań gospodarczych i kapitałowych miedzy miastami, [in:] K. Saganowski, M. Zagrzejewska-Fiedorowicz, P. Żuber (ed.), Ekspertyzy do Koncepcji Przestrzennego Zagospodarowania Kraju 2008-2033. Tom I, Ministerstwo Rozwoju Regionalnego, Warsaw, pp. 332-391.

Śleszyński, P. (2011). Social linkages, [in:] T. Komornicki, P. Siłka (ed.), Functional Linkages between Polish Metropolises, Studia Regionalia, 29.

Śleszyński, P. (2013). Warszawa jako ośrodek dojazdów pracowniczych. Studia Regionalne i Lokalne, 1 (51), pp. 5-25. DOI 10.7366/150949954500

Śleszyński, P. (2014). Delimitation and typology of functional urban regions in Poland based on commuting, 2006, Geographia Polonica, 87 (2), 317-320. DOI 10.7163/GPol.2014.20

Śleszyński, P. (2015). W sprawie optymalnego podziału terytorialnego Polski: zastosowanie analizy grawitacyjnej. Przegląd Geograficzny, 87 (2), 343-359. DOI 10.7163/PrzG.2015.2.7

Śleszyński, P. (2017). Dostępność ekonomiczna miast wojewódzkich w świetle kosztów dojazdu samochodem osobowym. Prace Komisji Geografii Komunikacji PTG, 2017, 20(1), 7-18. DOI 10.4467/2543859XPKG.17.001.6730

Werwicki, A. (1973). Struktura przestrzenna średnich miast ośrodków wojewódzkich w Polsce. Prace Geograficzne, Nr 101, PAN, Wroclaw, Warsaw.

Wiśniewski, S. (2017). The accessibility of Poland's Space to the Trans-European Transport Network. Miscellanea Geographica. 21 (3), 1-11. DOI 10.1515/mgrsd-2016-0030

Zaborowski, Ł. (2014). Sieć ośrodków regionalnych w Koncepcji Przestrzennego Zagospodarowania Kraju 2030. Próba uporządkowania według czynników wielkości i odległości. Przegląd Geograficzny, 86 (4), 591-619. DOI 10.7163/PrzG.2014.4.7

Zaborowski, Ł. (2016a). Próba przebudowy układu województw z wykorzystaniem sieci ośrodków regionalnych. Przeglad Geograficzny, 88 (2), 159-182. DOI 10.7163/PrzG.2016.2.2

Zaborowski, Ł. (2016b). Żeby Polska była Polską - a nie tylko Warszawą, Komentarz nr 177, Instytut Sobieskiego, Warszawa.

Vachudova, M. (2005). Europe Undivided: Democracy, Leverage, and Integration After Communism, Cambridge: Cambridge University Press.

Vickerman, R.W., Spiekermann, K. and Wegener, M. (1999). Accessibility and Economic Development in Europe, Regional Studies 33, pp. 1-15. DOI 10.1080/00343409950118878 